\title{
Využití sportu pravicovými extremisty
}

\section{Use of sport by the right-wing extremists}

\author{
Miroslav Mareš
}

Fakulta sociálních studií Masarykovy univerzity, Brno

\begin{abstract}
Abstrakt:
Text se zabývá rámcem pro analýzu využití sportu v pravicově extremistickém prostředí. Analyzuje situaci v extremistických politických režimech i subverzivních hnutích v různých historických obdobích, prèdevšim ve středoevropském kontextu. Za hlavní oblasti přitom identifikuje posilování identity organizací a hnutí, propagandu idejí a predstavitelư, infiltraci do občanské společnosti a mocenských struktur, př́pravu na násilné pưsobení, krytí jiných aktivit a útoky na protivníky.
\end{abstract}

\section{Abstract:}

This paper deals with framework for analysis the use of sport in the right-wing extremist environment. It analyses the situation in extremist regimes and in subversive movements in various historical periods, mostly in Central European context. As main fields it identifies strengthening of identity of organizations and movements, propaganda of ideas and representatives, infiltration in the civil society and power-structures, preparation of violent activities, cover-activities and attacks against opponents.

Klíčová slova: $\quad$ sport; pravicový extremismus; propaganda; paramilitarismus

Key words: $\quad$ sport; right-wing extremism; propaganda; paramilitarism

Tento príspèvek byl zpracován v rámci grantového projektu GAČR GA407/09/0100 „Soudobý paramilitarismus $v$ České republice v kontextu transnacionálních vývojových trendů politického násilí v Evropě“, financovaného Grantovou agenturou České republiky.

\section{ÚVOD}

Sport je fenoménem, který výrazně ovlivňuje soudobé společenské dění. Jeho popularita zapřičiňuje i to, že je silně propojen s politickou sférou. Sport je přitom využíván, resp. zneužíván také extremistickými politickými silami, a toto využití nabývá i bezpečnostní dimenzi. Platí to též pro pravicový extremismus. Danou problematikou se zabývá i tento článek. Jsou v něm vymezeny hlavní oblasti využití a zneužití sportu ze strany pravicových extremistů a demonstrovány na př́kladech ze zahraničí i z českého prostředí. V jednotlivých kapitolách jsou zohledněny jak záležitosti týkající se historických pravicově extremistických režimů, tak i subverzivního působení pravicových extremistů v demokratických režimech, a to s cílem demonstrovat jejich vzájemnou provázanost. $\mathrm{Na}$ tomto základě pak budou stanoveny i návrhy na postupy eliminující hrozby a rizika vyplývající z uvedeného využití.

\section{ZÁKLADNÍ VAZBA MEZI SPORTEM A PRAVICOVÝM EXTREMISMEM}

Pravicový extremismus je obecně definován jako soubor ideologií, postojů a činností, které směřují proti základním hodnotám demokratického ústavního státu. Pravicoví extremisté přitom zásadním způsobem popírají ideu lidské rovnosti před zákonem a usilují o institucionalizovanou nerovnost na základě paušálního pojetí údajně nadřazených a podřadných skupin lidí, vymezených zpravidla na zákla- 
dě biologického, národnostního anebo rasového původu, případně podle specificky pojatého sociálního výkonu (Mareš 2003: 22).

Sport jakožto prostor soupeření a vytváření kultu vítězů a poražených má u pravicových extremistů výraznou odezvu již od vzniku tohoto politického proudu v jeho moderním pojetí. Pravicoví extremisté sportovní prostředí využívají k různým účelům, přičemž jako nejvýznamnější lze vymezit:

1. posilování identity vlastních organizací a hnutí;

2. propagandu vlastních idejí a představitelů;

3. infiltraci do občanské společnosti a mocenských struktur;

4. př́ipravu na násilné působení;

5. krytí jiných aktivit;

6. útoky na protivníky.

Extremisté přitom mohou agitovat anebo nabývat vliv v již existujících sportovních strukturách a organizacích anebo mohou zakládat nové (pro extremistickou scénu i pro oslovení širší veřejnosti) (Landessportbund Niedersachsen e. V. - Sportjugend Niedersachsen 2009). Tyto formy budou $\mathrm{v}$ dalších částech článku demonstrovány a analyzovány na jednotlivých př́íladech, přičemž důraz bude kladen na středoevropské prostředí (nikoliv však výhradně na ně). Již na tomto místě je třeba zdůraznit fakt, že v řadě aspektů se výše uvedené formy doplňují anebo překrývají. Pravicový extremismus bude pojímán jako celek, protože využití sportu je u jednotlivých ideových variant velmi podobné. V některých dimenzích bude zmíněno využití sportu pravicově extremistickými režimy, převážná část př́ikladů však bude s ohledem na aktuální situaci vycházet především ze subverzivního působení pravicových extremistů v demokratických režimech. I u subverzivního působení je třeba rozlišovat propagandu legálně působících stran a skupin, a násilné a ilegální formy činnosti militantního spektra (i zde však může docházet k prolínání).

Je přitom třeba mít na paměti, že obdobným způsobem jako pravicoví extremisté mohou sport využívat (a často také využívají) i extremisté jiného zaměření, v propagandistické rovině a v oblasti posilování identity je pak sport důležitý i pro demokratické politické proudy a režimy (a jejich tajné služby jej mohou subverzivně využívat proti cizím mocnostem i k dalším z výše uvedených účelů).

U využití sportu pravicovými extremisty je přitom třeba věnovat specifickou pozornost především třem oblastem. První z nich jsou sporty, které jsou ve společnosti masově populární. Díky nim se mohou propagandisticky profilovat. $V$ př́ípadě masově populárních akcí (jako je např. olympiáda) do této kategorie spadají v zásadě všechny sporty. Jinak se ve většině evropských zemí jedná o fotbal, podle popularity v jednotlivých národních státech lze zmínit např. lední hokej v ČR a na Slovensku či basketbal v postjugoslávských zemích.

Druhou specifickou oblastí jsou úpolové sporty, přičemž podle Radima Pavelky a Jaroslava Sticha jsou úpoly „zaměřeny především na osvojení bojových technik pro soutěžení s cílem zlepšovat osobní výkon a vítězit Do úpolů zařazujeme i specifická cvičení, která jsou přímou průpravou na překonání partnera.“ (Pavelka, Stich 2011: 4). Úpolové sporty vyhovují silovému image řady pravicových extremistů a dovednosti v těchto sportech je možné využít při násilných aktivitách. Totéž platí pro různá bojová umění, která se mohou pohybovat na pomezí sportu a (para) militárního výcviku.

Třetí oblastí jsou branné sporty. Ty jsou důležité vzhledem $\mathrm{k}$ militaristické identitě velké části pravicových extremistů a jsou i vhodnou průpravou pro násilné a ozbrojené působení. Jako specifický podtyp branných sportů je přitom možné zmínit paintball a airsoft.

U všech výše uvedených sportů je třeba zdůraznit, že nejenom nelze klást rovnítko mezi nimi a pravicovým extremismem, ale nelze ani vyznavače těchto sportů a priori označovat za "potenciální extremisty“. Pravicoví extremisté mohou prostředí těchto sportů pouze využít, resp. zneužít, a to včetně manipulace jejich demokratickými vyznavači, kteří o působení extremismu ve svém vlastním sportu nemají informace anebo si nepřipouští negativa, které jsou s tímto působením spojená. 


\section{POSILOVÁNÍ IDENTITY VLASTNÍCH ORGANIZACÍ A HNUTÍ}

Obecně je důležitým atributem sportu vytváření kolektivní identity, a to jak mezi přímými účastníky sportovních soutěží, tak i mezi osobami, které vyjadřují jednotlivým sportovcům, týmům či celým sportovním odvětvím podporu zvnějšku. Širší sociální skupiny (např̀ národ) pak mohou být semknuty i díky zorganizování určité významné akce, např. olympiády. Posilování identity přitom prostupuje i všemi dalšími využitími sportu v oblasti pravicového extremismu (zpravidla mají takoví akce silné propagandistické využití).

Známým příkladem, který posílil semknutost pravicově extremistického režimu, byla olympiáda v nacistickém Německu, konaná v roce 1936 v Berlíně. Demonstrovala schopnost nacistického Německa uspořádat velkou akci a do jisté míry legitimizovala režim před vlastním obyvatelstvem, jehož část $\mathrm{v}$ tu dobu již byla výrazně postižena represemi a zločinnými praktikami režimu. Je přitom třeba zdůraznit, že hry byly Berlínu přiděleny již v roce 1931, tedy předtím, než se nacisté chopili moci (Bedürftig 2004: 326).

V současnosti již vzhledem $\mathrm{k}$ neexistenci ultrapravicových režimů není na mezistátní vládní úrovni možné uspořádat obdobnou pravicově extremistickou akci, jako byla berlínská olympiáda. Pravicoví extremisté neorganizují ani akce, kterých by se zúčastnili „běžní“ sportovci a oni je využili ke své propagandě. Jsou však uskutečňovány akce, na nichž přátelsky soutěží pravicoví extremisté z různých zemí.

Př́ikladem je „Mezinárodní letní tábor Slovenské pospolitosti“, který se uskutečnil ve dnech 24. až 26. července 2009 na Slovensku. Na akci se jednalo o možnostech spolupráce mezi tzv. národoveckými organizacemi (kromě organizátorů ze SP zde byli i zástupci Dělnické strany z ČR, polské Falangy a rumunské Nové pravice). V programu tábora byly soutěže v přetahování, zápasu a sportovní střelbě (Slovenská pospolitost' 2009).

Obdobné branně-sportovní tábory se uskutečňují i na vnitrostátní úrovni. Sounáležitost organizace však mohou utužit i jiné než jen branně sportovní aktivity, o čemž svědčí např. sportovní dny pořádané Dělnickou mládeží, během nichž je organizován fotbalový turnaj (mužstva většinou vytvoří místní organizace nebo spřízněné gangy). $\mathrm{V}$ situaci, kdy byl vzhledem k povaze organizace problém s pronájmem vhodného sportoviště, je tato skutečnost využita i k propagačním účelům, resp. ke kritice represe vůči DM (Lamprecht 2010). Vlastní sportovní dny pořádá i neonacistická organizace Národní odpor (Útvar pro odhalování organizovaného zločinu 2010).

V př́ípadě, že se ve sportovním prostředí vytvoří místa, kde se stabilně setkávají prríslušníci ultrapravice, jako jsou např. boxerské kluby či fit-centra (což často souvisí se začleněním jejich majitelů do tohoto prostředí), je takové místo - včetně étosu jeho názvu - důležité pro místní scénu, především na lokální úrovni. Mladý člověk usilující o nalezení kolektivu, v němž by našel uspokojení, má snahu pravidelně docházet do takového prostředí, kde se mu dostává i ideologické indoktrinace.

Někdy však využití klubových či obdobných sportovních motivů k vyjádření identity není iniciováno ze strany jejich majitelů či členstva. Př́kladem je obliba značky Lonsdale (britský boxerský klub a oděvní značka), kterou neonacisté uznávají jednak pro obecný násilný étos, jednak proto, že v názvu jsou po sobě jdoucí písmena NSDA připomínající zkratku NSDAP. Samotná firma Lonsdale se přitom od rasismu a neonacismu distancovala (Mareš 2006: 59). Význam značky může být i zdrojem identitárních problémů, což se ukázalo v případě značky Fred Perry, pojmenované po úspěšném britském tenistovi, který pocházel z dělnické tř́ídy a byl populární mezi skinheads s obdobnými kořeny. Neonacisté však značku odvrhli, když se mezi nimi rozšiřilo povědomí o Perryho židovském původu (Mareš 2006: 58).

Roli při utužení ultrapravicových kolektivů sehrává i společná návštěva sportovních utkání a dalších událostí. Zcela specifickou roli má sportovní, resp. quasisportovní prostředí pro identitu pravicově extremistických chuligánských gangů. Ty jsou vázány na fotbalové kluby a někdy se koncentrují i kolem národních mužstev. Chuligánství je jevem, který nemusí být spojen s prosazováním ideových zájmů, může však nabýt i politickou dimenzi, včetně pravicově extremistické (Smolík 2008: 115-116). Část ultrapravice však kritizuje chuligánství jako jev, který diskredituje nacionalistickou scénu. 


\section{PROPAGANDA VLASTNÍCH IDEJÍ A PǨEDSTAVITELŮ}

Sportovní prostředí je s ohledem na masový charakter sportu vhodné i k propagaci vlastních idejí a představitelů, což se týká především masově populárních sportů a snahy využít známé sportovce pro podporu ultrapravicových organizací. V prostředí vhodném pro propagaci se přitom:

(a) mohou pohybovat ultrapravicoví propagandisté bez přímého napojení na sportovce,

(b) mohou být sportovci propagačně využíváni bez svého vědomí a souhlasu s tímto využitím,

(c) s částečným souhlasem sportovců (např. užívání nacistického pozdravu na olympiádě v Berlíně zahraničními účastníky) nebo

(d) mohou být sportovci př́mými agitátory anebo

(e) organizátory ultrapravicových aktivit.

Propaganda přitom může být pozitivní (ve smyslu propagace vlastních cílů) nebo negativní (zaměřená proti protivníkům pravicových extremistů), možná je samozřejmě i kombinace.

Klasickým propagačním využitím propagandy pro politický režim byla již zmíněná berlínská olympiáda, i když v jejím rámci byly určité rysy nacistické ideologie spiše potlačovány, než hlásány ve zvýšené míře (rasismus, antisemitismus). Pro pravicově extremistický režim je pak důležité, pokud jeho sportovci uspějí v mezinárodním soutěžení. Tento propagandistický zájem je spojen i s rizikem neúspěchu, což se ukázalo při již zmiňovaných olympijských hrách v Berlíně, jejichž hvězdou se stal afroamerický atlet Jesse Owens, jehož úspěch narušoval nacistické rasové teorie. Jinak však tyto olympijské hry posloužily nacistické propagandě. Němečtí sportovci získali nejvíce medailí. Jak uvádí Friedmann Bedürftig: „Hitler byl patronem her a při svých téměř každodenních výstupech na olympijském stadionu, provázených výbuchy jásotu i nadšení, se prezentoval jako svrchovaně populární státník“ (Bedürftig 2004: 326).

$\mathrm{V}$ současnosti je některými pravicově extremistickými subjekty využíváno sportovní prostředí $\mathrm{k}$ tomu, aby bylo kritizováno narušení tradiční národní identity západních zemí, když je více či méně otevřeně kritizováno pronikání hráčů s imigrantským původem do národních týmů. Místopředseda Dělnické strany sociální spravedlnosti Jiří Štěpánek shrnul v Dělnických listech postoje k uvedenému tématu ve vazbě na neúspěch francouzského mužstva na MS v roce 2010 následovně: „K problému se vyjádřila i Front National J.-M. Le Pena, která prohlásila, že mužstvo nesymbolizuje Francii, kde valná většina obyvatel je ještě bílá. Ano, mužstvo Francie už několik let připomíná spíše afro-arabsko-karibský výběr a osobně pochybuji, že některému z hráčů něco ř́íká Francie se svou historií a tradicemi. Oni mají pouze francouzský pas, přes rok hrají v klubech po celé Evropě a mistrovství světa považují za jakousi osobní prezentaci kvůli případnému novému klubovému angažmá. Byla to také Front National, jež už před mnoha lety, tuším, že na mistrovství v roce 1998, poukazovala na fakt, že reprezentanti Francie, kteří jsou Francouzi pouze pasem, neumějí francouzskou hymnu. Při televizních záběrech bylo vidět, že tito hráči při hraní Marseillaisy pouze koukají, protože neznají slova. Podobné výtky zazněly i od německé NPD, která poukazovala na stejný fakt. Když už jsme u německého mužstva, tak to má ve svém kádru 13 cizinců (Němců, kteř́i jsou Němci pouze pasem)... V roce 1990 nemělo německé fotbalové mužstvo jediného cizince... Ano, i fotbal promlouvá do politiky a celospolečenských témat a dokazuje, že všechno souvisí se vším. Nesmyslná multi-kulti politika se tahá i do sportu a pak jsou vidět ty konce. Vše národní je pošlapáváno a zlehčováno. Evropa se probouzí (tedy spíše etničtí Evropané, vrcholní politici zatím ne) ze svého „všerasového“ snu a začíná si uvědomovat své kořeny, tradice a identitu“ (Štěpánek 2010). Je třeba zmínit, že na této propagandě se sami fotbalisté většinou nepodílejí.

Dalším příkladem propagandistických aktivit bez vědomí sportovců je velká část agitace pravicově-extremistických chuligánských gangů v hledištích fotbalových stadionů. Na jejich transparentech jsou využívány symboly a hesla, která více či méně otevřeně propagují politické ideje. Časté je ve světě např. využití keltského kříže, který v pravicově extremistickém prostředí slouží k vyjádření identity evropského nacionalistického dědictví (Smolík 2008: 118).

$\mathrm{V}$ určitých případech je využití sportovců v politické propagandě extremistických subjektů způsobeno spíše jejich neznalostí politického prostředí anebo neutrálním postojem ke všem politickým stranám a hnutím. Např. kontext jejich rozhovoru pro vybranou tiskovinu jim pak nemusí být zcela jasný. 
Př́kladem je rozhovor tehdejšího úspěšného hokejisty Vladimíra Růžičky pro týdeník Republika (blízký SPR-RSČ), který v roce 1998 vedl Tomáš Vandas, a který pak byl využit v republikánské propagandě.

Sportovci mohou vyjít vstříc náladám extremisticky naladěného davu svých fandů, i když extremistické ideje nepodporují. Př́́kladem je zřejmě neuvážené gesto tehdejšího útočníka Sparty Praha Horváta, který směrem ke skupině spartanský fandů naznačil rukou pohyby připomínající hajlování. Sám Hortváth ovšem tvrdil, že jeho cílem bylo fanoušky pouze uklidňovat a od rasismu i nacismu se distancoval (Fotbal.Sport.cz 2007).

Sportovci však mohou být extremisticky orientováni a mohou dávat tuto extremistickou orientaci najevo. Mediálně známým je v tomto směru př́ípad hráče Lazia Roma Paola di Cania, který zdravil své fanoušky fašistickým pozdravem, vyjadřoval se antisemitsky a neskrýval obdiv k Benitu Mussolinimu (Smolík 2007: 120). Fotbalista tak ideově podporoval příznivce klubu, mezi nimiž jsou fašistické ideje populární.

Pravicově extremistické subjekty mohou pro svoji činnost získat i sportovce (včetně bývalých), kteří se v době své sportovní kariéry takto politicky neprojevovali. Následně je využívají pro vlastní propagaci a mobilizaci příznivců. Př́́kladem je př́klon bývalého vzpěrače a olympijského vítěze Oty Zaremby k Dělnické straně sociální spravedlnosti v roce 2010. Důvodem jeho vstupu byl jednak souhlas s programem strany a jednak - podle rozhovoru pro časopis Týden - skutečnost, že ho prý okradli Romové. Následně prý vyhodil všechny Romy ze svého klubu (Šanda - Zlatohlávek 2010).

\section{INFILTRACE DO OBČANSKÉ SPOLEČNOSTI A MOCENSKÝCH STRUKTUR}

Sportovní aktivity slouží pravicovým extremistům i jako prostředek infiltrace do občanské společnosti a mocenských struktur. Začleněním do sportovních uskupení posilují svoji pozici, z níž mohou ovlivňovat společenské a politické dění. Rozhodnutí o sportovních záležitostech mohou dostávat i politický extremistický podtext (napr. ve vztahu k chuligánským gangům na fotbalových stadionech, pokud je mezi funkcionáři jejich bývalý člen). V režimech s extremisty u moci je pak kontrola sportovního působení důležitá pro zajištění dohledu nad obyvatelstvem a specifiky pak nad mládeží.

Již nacistický režim v Německu se snažil o silnou pozici sportu, která byla propojena s celkovým charakterem režimu a vládnoucí ideologie. Všechny oficiální sportovní aktivity byly centralizovány, především do Německého říšského svazu pro tělesnou výchovu (DRL). Silně sport působil zvláště na mládež. Jak uvádí Brenda Ralphová-Lewisová: „Život v Hitlerově mládeži byl pečlivě naplánovanou kombinací náročných sportovních aktivit, vzrušující zábavy, disciplíny, donucování a indoktrinace. Osobitý důraz se kladl na ideál fyzické dokonalosti dosahované pro větší slávu vlasti“ (Ralphová-Lewisová 2001: 47). Modely ovlivňování mládeže prostřednictvím sportu se přenesly i do okupačních a kolaborantských režimů v Evropě, mj. do Kuratioria pro výchovu mládeže v Protektorátu Čechy a Morava.

V současnosti hraje infiltrace do sportovního prostředí důležitou roli ve strategii německého neonacismu, která je charakteristická pro Národně demokratickou stranu Německa (NPD) a s ní propojené kamarádské spolky. Tato strategie spočívá na čtyřech pilírích - boji o ulice, boji o hlavy, boji o parlamenty a boji o organizovanou vůli, tzv. strategii lidové fronty (Miliopoulos 2007: 123-136). V rámci boje o ulice se snaží získat co nejvíce aktivistů na svoji stranu, a proto se infiltrují do různých struktur občanské společnosti (např. hasičských dobrovolných spolků), včetně sportovních.

V současném Německu již nabyl tento průnik do sportovních spolků, v nichž je organizována velká část mládeže, poměrně masový rozměr. Spolky jsou následně relativně nenápadně přebudovávány na základnu pravicového extremismu. Podle některých informací se tak děje i tím, že v takových spolcích je preferován zpěv první sloky „Deutschlandslied“ (která je německou hymnou) - tedy „Deutschland, Deutschland über alles“, nikoliv „Einigkeit und Recht und Freiheit“ (Mayntz 2011). Zpěv první sloky této písně (která byla hymnou i v období nacistického Německa, ale pochází již z 19. století) není ilegální, ale v kontextu neonacistické infiltrace má specifický symbolický význam.

Pravicově extremističtí chuligáni se mohou postupně stát i funkcionáři fotbalových klubů, s nimiž jsou spjati, a následně ke svým idejím směrovat celý klub. Dosud však nejsou známy potvrzené př́ílady tohoto jevu. Spekulace provázejí př́ípad Tomáše Straky, který se stal v roce 2011 viceprezidentem Slovanu 
Bratislava pro styk $s$ fanoušky. Někteří autoři upozorňují na jeho předchozí působení v prostředí radikálních př́znivců klubu, kterým tito autoři přisuzují i rasistické a neonacistické projevy (Danilov 2011). Nicméně doposud se nepotvrdilo, že by tato aktivita sledovala nějaký infiltrační strategický cíl a ve funkci se - pokud je známo - Straka nijak extremisticky neprojevuje.

Obdobně provázejí spekulace př́ípad osob působících v Brně na počátku nového tisíciletí v Johny Kentus Gangu s neonacistickým zaměřením, osob, které začaly působit v bezpečnostní agentuře zajištující bezpečnost na sportovních utkáních. I přestože se dopustili některých excesů, není pravděpodobné, že by se tak stalo s nějakým strategickým kalkulem, resp. že by jejich činnost byla cílenou infiltrací klubových struktur, a to ani ve smyslu nasazení bývalých respektovaných chuligánů ke „zklidnění těch mladých“ (což je model, využívaný v některých zahraničních zemích, Albrecht 2011).

\section{PŘíPRAVA NA NÁSILNÉ PŮSOBENÍ}

Sportovní prostředí je vzhledem k charakteru sportu, zvláště pak jeho vybraných druhů, vhodné i pro přípravu na násilné působení ve prospěch extremismu. Zvláště důležité jsou v tomto směru úpolové sporty a branné sporty. V Německu je dokonce pojem branný sport používán často pro označení různých výcvikových táborů a kampů krajní pravice v obdobném významu, v jakém jsou v ČR či jinde ve světě použíány pojmy paramilitární či branná cvičení.

Sportovní výchova byla úzce prolnuta $\mathrm{s}$ brannou výchovou a př́pravou na boj již v nacistickém Německu. Již výše citovaná Brenda Ralphová-Lewisová ke sportu ve Třetí řiši v prostředí Hitlerovy mládeže uvádí: „Nešlo však pouze o nějaké samoúčelné cvičení pro zdraví či nadýchání se čerstvého vzduchu. Sport tvořil v nacistickém Německu arénu, v níž se rodilo válečné prostředí, v níž sílil pocit vlastenecké sounáležitosti, kde se chlapci oddávali takovým násilnostem, které jinak připadají v úvahu pouze na bitevním poli. Zkrátka a dobře, přirozenou chlapeckou agresivitu - strkání, tahání, pěstní potyčky a napadání slabších členů skupin - tvořící normální, třebaže někdy bolestivou součást růstu, bylo třeba usměrnit do určitých kolejí. Toto využití sportu nebylo samozřejmě příznačným jevem pouze pro Německo. I v Anglii se například pěstovaly stejně drsné soutěživé sporty, i když s poněkud jiným cílem: vypěstovat smysl pro férovou hru, týmového ducha či velkorysost ve vítězství a nezatrpklost v porážce. Nacistické pojetí však bylo naprosto odlišné. Sport v hitlerovském Německu neznamenal víc než touhu po vlastní dokonalosti, pěstování odvahy a koneckonců okázalé projevování ctností nadřazené rasy... Fyzická zdatnost, rasová a politická nadřazenost, jakož i vítězství panské rasy byly pojmy, jež se proto $\mathrm{v}$ nacistickém Německu navzájem prolínaly, nebot konečným cílem bylo vypěstovat vládnoucí tř́ídu naprosto loajální státu a spolu s ní i ozbrojené složky s chrabrostí, vojenskou připraveností a věrností Německu na takové úrovni, jakou ještě nikdo na světě nespatřil“ (Ralphová-Lewisová 2001: 47-50).

$\mathrm{V}$ podobném duchu je vedena i soudobá prŕprava neonacistických militantů. $V$ manuálu, zveřejněném pro bojovníky organizace Combat 18 , kde byli mladí aktivisté vyzýváni k vytvoření týmů, se mj. uvádí: „I vy si vyberte správné kamarády, nehledejte je však jen v hospodě u piva. Poznat někoho neznamená s ním jen sedět a vykládat v hospodě. Chodte do posilovny, sportovního klubu, vyjíždějte na víkendy do lesa apod. Ovšem nespoléhejte jen na to, skutečnou prověrkou je pouze opravdový boj! Někdo se může při výcviku chovat jako nefalšovaný profesionál, ale v boji zklame. Vybírejte pečlivě své kamarády, ale hlavně se snažte pracovat sami na sobě! Jak? Navrhni ty sám svým kamarádům společný trénink $\mathrm{v}$ posilovně, přihlaste se do kteréhokoliv bojového sportu, vyjedte si spolu do př́rody, skočte si společně padákem apod. ... První a nejdůležitější je fyzická kondice a psychická odolnost každého z vás. Posilujte, cvičte, plavte, zkrátka aktivně se věnujte některému sportu. Dbejte na svou fyzickou kondici a neustále ji zvyšujte. Postačí se jí věnovat jen několik hodin týdně, každý z vás si na to jistě čas najde. Udělejte si ze cvičení neoddělitelnou součást svého života!“ (Combat 18: 2000).

Je zajímavé, že v posilovně získávali sebevědomí a dovednosti i pachatelé některých závažných trestných činů v současnosti. Př́́kladem v ČR je Ivo Müller - jeden $\mathrm{z}$ tzv. vítkovských žháŕů, kteří v dubnu 2009 uskutečnili útok na dům obývaný romskou rodinou, při němž byla těžce popálena dvouletá dívka. Podle informací zveřejněných v médiích byl pravidelným návštěvníkem posilovny (Kuba 2009). Není však prokázaná přímá souvislost mezi tímto výcvikem a útokem. Takovou souvislost však lze nalézt 
např. u ruského kickboxera a neonacisty Vjačeslava Dacika, který během první dekády využíval získané sportovní schopnosti k politickému násilí i ke kriminálním aktivitám (Kenyky 2010).

\section{KRYTÍ JINÝCH AKTIVIT}

Sportovní aktivity mohou extremistům sloužit i pro krytí jiných aktivit, které jsou zpravidla chápány jako ilegální. Již pravý účel sportovní přípravy na násilné působení (uvedený v předchozí části) je ze strany extremistů většinou utajován (zvláště při subverzi v demokratických zemích). Sportovní činnost však může přikrýt i další aktivity, o jejichž zveřejnění nemají extremisté zájem.

$\mathrm{Na}$ úrovni politického režimu se může jednat o snahu zatajit záležitosti vojenského charakteru. V době, kdy byly v rámci Versailleského systému na Německo uvaleny sankce, nesmělo disponovat vlastním letectvem. Již v období Výmarské republiky se proto část leteckého výcviku odehrávala pod rouškou plachtařských sportovních soutěží (Brühl a kol. 1985: 495). Po nástupu nacistů k moci v březnu 1933 byly německé letecké sportovní spolky sloučeny do nově založeného Leteckého sportovního svazu, který byl úzce provázán s SA a SS (užíval se v něm i tzv. „německý pozdrav“) a jeho struktury a výcvik v jeho rámci vytvořily předpoklad pro vznik Luftwaffe (Absolon 1998: 62).

Ve Třetí ř́šsi sport nacisté využili i k tomu, aby přikryl jejich zločiny proti lidskosti. Když přijely delegace Červeného křiže ze Švédska do ghetta Terezín, byly jim mj. prezentovány zinscenované fotbalové zápasy zde vězněných Židů, aby nacisté prokázali „normálnost“ zdejšího života. Delegáty se podařilo oklamat, o čemž svědčí i zpráva delegáta M. Rossela, vypracovaná po návštěvě 23. 6. 1944. Mj. se v ní o terezínském ghettu uvádí: „Fotbal se praktikuje v širokém měřítku, mužstva se sestavují dvěma způsoby, na základě pracovního zařazení, např́íklad kuchaři proti pekařům, nebo podle původu hráčů, např́iklad Berlín proti výběru Vídeň-Praha... Nejrozšířenějším sportem českých Židů je odbíjená" (Rossel 1944).

Sportovní aktivity sloužily nacistům i k přikrytí subverze vůči nepřátelským státům, včetně Československa. V tomto směru je charakteristická činnost organizace Volkssport (Lidový sport), což byla $\mathrm{v}$ zásadě dceřinná organizace Německé národně socialistické dělnické strany $\mathrm{v}$ meziválečném Československu. Tato organizace byla státem povolená v roce 1929 a do roku 1932, kdy byla zakázána, se rozrostla z pěti tisíc na čtyřicet tisíc členů, přičemž se strukturou i uniformami podobala SA (Beran 2009: 257). S vedoucími činiteli Volkssportu se konal proces, v němž byli odsouzeni „pro útoky proti republice, spojenectví s cizími činiteli, organizování ozbrojených sil v souvislosti s nacistickou ideologií, jejímž tajným konečným cílem je násilné odtržení části území republiky (Beran 2009: 260).

Zákaz Volkssportu neznamenal, že by tyto aktivity v rámci sudetoněmeckého neonacistického hnutí ustaly. V souvislosti se sportovními akcemi v Německu docházelo k pašování zbraní. Jak uvádí Jiří Cihlář v práci o nástupu nacismu na Orlickoústecku, Sudetoněmecká strana „vysílala do Německa mladé členy na několikatýdenní vojenský výcvik. K tomu jim daly př́ležitost i Sportovní a turnerské slavnosti ve Vratislavi. 15. srpna 1938 zadržela policie na nádraží v Dolní Lipce zámečnického učně H. Proksche. Měl u sebe dýku s hákovým kř́ižem a nápisem Blut und Ehre (Krev a čest), 150 nábojů do pistole, fotoaparát, protičeskoslovenské letáky a potvrzení, že je v Krasíkově ordnerem, s fotografií v uniformě Hitlerovy mládeže a páskou s hákovým křížem na rukávě“ (Cihlář 2000: 83).

Na výcvikové „branně-sportovní aktivity“ jsou další negativní jevy navázány i u soudobých neonacistů. Např. Branně-sportovní skupina Hoffmann (Wehrsportgruppe Hoffmann), která působila v sedmdesátých letech ve Spolkové republice Německo a po zákazu v této zemi se částečně př̌esunula do Libanonu, poskytovala svým členům vojenský výcvik a nabízela i žoldnéřské služby (mj. pro tehdejší rasistický režim v Rhodesii) (Herb 1980: 31).

Specifické zprostředkované napojení na organizovaný zločin existuje u některých fotbalových chuligánských gangů s dílčím extremistickým pozadím, které jsou zapojeny do obchodu s drogami a se zbraněmi (Mareš, Smolík, Suchánek 2004: 61). Mobilita chuligánských gangů a jejich výjezdy do různých zemí jsou výhodou pro uvedené kriminální aktivity. Jejich násilné prostředí pak vytváří i lokální symbiózy s organizovaným zločinem na lokální úrovni, zvláště pokud se z prostředí chuligánských gangů rekrutují vůdci kriminálního prostředí, např. v polské Wroclavi (Polská policie 2010). 


\section{7. ÚTOKY NA NEPŘÁTELE}

Ve sportovním prostředí může docházet i $\mathrm{k}$ prrímým útokům na nepřátele pravicových extremistů. Může se jednat o "rozšíření propagandistického působení jinými prostředky“ i o snahu o aplikaci diskriminačních a represivních norem v praxi, představit si lze i využití sportovního prostředí pro přímé likvidační akce.

V nacistickém Německu byli Židé vystaveni represi a diskriminaci i ve sportovním prostředí. Již v roce 1936 jim bylo ve stanovách zakázáno členství v Německém říšském svazu pro tělesnou výchovu (Bedürftig 2004: 303), což časově odpovídá i aplikaci rasistických protižidovských norimberských zákonů obecně.

V současnosti se zřejmě nejčastěji projevuje přímé násilí v prostředí pravicově-extremistických chuligánských gangů, zvláště při jejich násilí vůči skupinám odlišné ideové orientace (zvláště levicově extremistickým), případně k útokům na policii z politických důvodů (přičemž identifikovat, zda se v konkrétním př́padě jedná o útok primárně motivovaný nepolitickou agresivitou či politickým přesvědčením, je mnohdy velmi obtížné, zvláště pokud je veden útok pod vlivem alkoholu apod.). Př́ikladem jsou střety mezi neonacisty z gangů při Spartě Praha a anarchisty z gangů kolem Bohemians Praha v první polovině první dekády (Mareš, Smolík, Suchánek 2004: 145).

Na rozdíl od situace, kdy o střety mají obě strany zájem, dochází i k napadání nezúčastněných obětí. Př́kladem jsou útoky pražských neonacistů na kolemjdoucí - včetně alternativní mládeže a těhotné ženy - při oslavách vítězství českých hokejistů na mistrovství světa v roce 1999, přičemž důležitou roli v těchto útocích hrál agresivní militant František Sobek (Mareš 2005: 201).

Násilí vyvolané chuligánskými gangy může přerůst i do rozsáhlejších etnických nepokojů, jak tomu bylo v britském Oldhamu v roce 2001 nebo koncem roku $2010 \mathrm{v}$ Rusku, kde byl při střetu mezi příznivci klubu Spartak Moskva a skupinou Kavkazanů jeden z ruských mladíků zabit. Následovaly masové nepokoje, které musela po náročných operacích zastavit policie a vyjádřil se $\mathrm{k}$ nim i ruský prezident Medveděv. Novinářka Petra Procházková popsala situaci následovně: „Asi 5 tisíc odhodlaných mladých lidí se v sobotu shromáždilo v centru Moskvy, vzápětí začali napadat občany snědé pleti, surově je bili a pronásledovali. Menší skupinky Rusủ honily migranty z Kavkazu a střední Asie i v metru a okrajových částech města. Na různých místech byl zavražděn jeden Kyrgyz a jeden Ázerbájdžánec. Policie musela tvrdě zasáhnout“" (Procházková 2010).

Vyloučit nelze ani ultrapravicový terorismus namířený proti nepřátelům, at již selektivní proti konkrétním sportovcům (kteří jsou i terčem verbálních výpadů, jako je např. bučení na hráče černé pleti na stadionech), anebo proti celým týmům i publiku na sportovních utkáních. $\mathrm{V}$ tomto směru je však v současné době jako rizikový aktér nahlížen především islamistický terorismus, ze strany ultrapravice by však mohla následovat obdobná odveta (např. na islámské fotbalové turnaje).

\section{PROTIOPATŘENÍ}

Vůči všem formám využití (resp. zneužití) sportovního prostředí je možné přijímat i protiopatření, která musí odpovídat charakteru konkrétní interakce sportu a pravicových extremistů. Je pochopitelné, že pokud jsou pod pláštíkem sportovního letectví budovány vojenské síly, je třeba diplomatická a případně i ozbrojená akce (což se v období vzniku nacistických ozbrojených sil nestalo). Různé krycí aktivity je možné sledovat i zpravodajskými prostředky.

$\mathrm{V}$ demokratické společnosti je možné proti různým násilným, krycím i propagandistickým aktivitám postupovat zpravodajskými i policejními prostředky, resp. právní represí. Ta pak může mít i další účiny - např. proces s Volkssportem byl důležitým faktorem pro zákaz DNSAP (Beran 2009: 260-261). V tomto kontextu je však třeba zdůraznit, že zpravidla neexistuje něco jako čistě protiextremistické právní normy specializované na sportovní prostředí, protože na tuto problematiku lze aplikovat šíře koncipované právní předpisy.

Kromě oficiální represe a právních postihů lze proti působení pravicových extremistů ve sportu využít i obecné kulturní a morální normy, případně obecné i konkrétně zaměřené (např. protirasistické) interní normy sportovních organizací. Na mezinárodním poli je specifickým prostředkem bojkot sportovních 
událostí, přičemž zpravidla největší pozornost poutají bojkoty olympijských her. Snahy o rozsáhlý bojkot olympijských her v Berlíně v roce 1936 však nebyly dotaženy do konce, plánovaný bojkot olympijských her v Tokiu v roce 1940 nemohl kvůli jejich neuskutečnění nabýt reálnou podobu (Kolář 2010: 108). Na mezinárodním sportovním poli byla Jihoafrická republika ostrakizována v závěrečné fázi tamního apartheidu.

$\mathrm{V}$ politickém prostředí demokracie či neustálených politických poměrů se jako alternativa proti pravicově extremistickým sportovním spolkům mohou stavět spolky demokratické či levicově extremistické orientace. Př́ikladem demokratického sportovního spolku je např. Dělnický turnerský a sportovní svaz (ATUS), který působil mj. v obranné roli proti nacismu v Československu v kritické druhé polovině třicátých let (Kössl, Štumbauer, Waic 2004).

V demokracii je ovšem pochopitelná i snaha, aby zde pravicově extremistické organizace vůbec nevznikaly, př́ípadně aby do nich extremisté nepronikali, ani nevyužívali sportovní prostředí ke své propagandě. Proto je v zemích, kde se tento problém vyskytuje, někdy uskutečňován proti všem uvedeným jevům i rozsáhlejší program, což je i př́klad soudobé SRN a tamního společného působení složek $\mathrm{v}$ resortech ministerstva vnitra a ministerstva sportu (Landessportbund Niedersachsen - Sport-JugendAgiert 2009; Mayntz 2011). V těchto kampaních hraje podstatnou roli prevence před negativní interakcí sportu s pravicovým extremismem.

Nejpropracovanější jsou postupy proti rasismu (který s pravicovým extremismem úzce souvisí) ve fotbalovém prostředí, kde zvláště na evropské úrovni existuje komplex norem i sít vládních i nevládních organizací zaměřená na tento fenomén, přičemž dominantní roli má antirasistická FARE (Football Against Racism in Europe), která disponuje několika důležitými členskými organizacemi na národní úrovni (Smolík 2008: 211). Projevy rasismu monitoruje, analyzuje, potírá (ve spolupráci s dalšími složkami) a snaží se jim předcházet výchovnými a alternativními programy.

\section{ZÁVĚR}

Sportovní prostředí je výraznou arénou pro působení pravicového extremismu, který zde více či méně systematicky posiluje svůj vliv. Interakce sportu a pravicového extremismu má přitom dlouhou historickou tradici, vázanou i na existenci historických ultrapravicových režimů. Ve všech oblastech využití sportu ze strany pravicových extremistů je patrný kontinuální dynamický vývoj a lze předpokládat, že pravicoví extremisté budou uvedené způsoby využití dále precizovat. Proti tomuto působení však existuje i systém protiopatření na mezinárodní i vnitrostátní vládní i nevládní úrovni, který umožňuje relativně účinnou eliminaci rizikového prolnutí sportu a pravicově extremistických aktivit.

\section{Literatura}

\section{Primární zdroje}

ALBRECHT,P.Bezpečnostpřifotbalevrukouextremistů[online].ČT24.Posl.úpravy26.04.2011 [cit.2011-0510].DostupnénaWWW: $<$ http://www.ct24.cz/sport/122229-bezpecnost-pri-fotbale-v-rukou-extremistu/ printversion/>.

COMBAT 18. Taktika. Posl. Úpravy neoznačeny. Combat 18, 2000. [cit. 2000-09-26]. Dostupné na WWW $:<$ http://members.fortunecity.com/raistlin33/combatm.htm>.

DANILOV, S. Zaujímavé rošády vo futbalovom Slovane. [online]. Danilov.blog.sk Posl. Úpravy 25.02.2011 [cit. 2011-05-10]. Dostupné na WWW:< http://danilov.blog.sme.sk/c/257642/Zaujimave-rosady-vofutbalovom-Slovane.html\#t2>.

FOTBAL.SPORT.CZ. Horváth dostal za hajlování pokutu 200 tisíc korun [online]. Fotbal.Sport.Cz Posl. Úpravy 06.09.2007 [cit. 2011-05-09]. Dostupné na WWW:< http://fotbal.sport.cz/clanek/117680-horvath-dostal-za-hajlovani-pokutu-200-tisic-korun.html>.

KENYKY. Odvrácená tvář Viacheslava Datsika: Z psychiatrie zpátky do vězení. Kickboxing. Posl. úpravy 25. 10. 2010 [cit. 2011-05-13]. Dostupné na WWW $:<$ http://kickboxing.blog.cz/1009/ odvracena-tvar-viacheslava-datsika/>. 
KUBA, F. Tři žháři z Vítkova chodili na stejnou školu. [online]. Denik.cz. Posl. úpravy 24. 9.2009 [cit. 2011-05-13]. Dostupné na WWW :<http://www.denik.cz/regiony/tri-zhari-z-vitkova-chodili-20090924. $\mathrm{html} />$.

LANDESSPORTBUND NIEDERSACHSEN E. V. - SPORT-JUGEND-AGIERT: Rechtsextremismus im Sport - Erscheinungsformen. [online], 2009, [cit. 2011-05-08]. Dostupné na WWW: $<$ http://www. sportjugend-nds.de/ps/tools/download.php?file=/live/lsb_nds/lsb_dms/psfile/docfile/76/09_12_07_ s4bcda138bed2c.pdf\&name=09_12_07_sporechtsergänz.pdf\&disposition=attachement $>$.

LAMPRECHT, E. Sportovní den č. 2. [online], Dělnická mládež, 2010, Posl. Úpravy 12.07.2010 [cit. 201105-07]. Dostupné na WWW:< http://www.delnickamladez.cz/sportovni-den-dm-cislo-dve>.

MAYNTZ, G. Neonazis unterwandern Sportvereine. [online], RP online, 2011, posl. Úpravy 19.01.2011 [cit. 2011-05-10]. Dostupné na WWW:< http://www.rp-online.de/politik/deutschland/Neonazisunterwandern-Sportvereine_aid_954404.html> .

POLSKÁ POLICIE: Sdělení autorovi ze strany př́íslušníka polské policie, 2010.

PROCHÁZKOVÁ, P. Ruští fotbaloví fanoušci s nacionalisty útočí na Kavkazany [online].. Lidové noviny 2010. Posl. úpravy 14. 12. 2010 [cit. 14. 5. 2012], Dostupné na WWW:< http:// www.lidovky.cz/rusti-fotbalovi-fanousci-s-nacionalisty-utoci-na-kavkazany-pqr-/ln_zahranici. asp?c=A101214_093638_ln_zahranici_mtr $>$.

ROSSEL, M. Ghetto Terezín. Navštíveno 23. 6. 44 (překlad Pavel Stránský) [online]. Holocaust.cz, 1944. Posl. úpravy 9. 6. 2009 [cit. 14. 5. 2011], Dostupné na WWW: $<$ http://www.holocaust.cz/cz2/resources/ texts/rossel>.

SLOVENSKÁ POSPOLITOST. Medzinárodný letný tábor Slovenskej pospolitosti. [online], Slovenská pospolitost', 2009, Posl. Úpravy 26.07.2009 [cit. 2011-05-07]. Dostupné na WWW:< http://www.pospolitost.org/nasa\%20cinnost/akc09/lettabor.html>.

ŠANDA, K. - ZLATOHLÁVEK, R. Zarembu okradli Romové, tak vstoupil do Dělnické strany [online]. Posl. Úpravy 14.07.2010 [cit. 2011-05-07]. Dostupné na WWW <http://www.tyden.cz/rubriky/domaci/ zarembu-okradli-romove-tak-vstoupil-do-delnicke-strany_175380.html>

ŠTĚPÁNEK, J. Konec multi-kulti fotbalu? [online], Dělnické listy, Posl. Úpravy 30. 10. 2010 [cit. 2011-0514]. Dostupné na WWW <http://www.delnickelisty.cz/konec-multi-kulti-fotbalu_?print>

ÚTVAR PRO ODHALOVÁNÍ ORGANIZOVANÉHO ZLOČINU. Zpráva o činnosti ÚOOZ za rok 2009 [online].. Praha: ÚOOZ SKPV PP PČR, 2010 Posl. Úpravy 14.07.2010 [cit. 2011-05-07]. Dostupné na WWW < http://www.policie.cz/clanek/zprava-o-cinnosti-uooz-zprava-o-cinnosti-uooz-za-rok-2009.aspx>

\section{Odborná literatura:}

ABSOLON, R. Die Wehrmacht im Dritten Reich. Band I. 30. Januar 1933 - 2. August 1934. München: Boldt im Oldenbourg Verlag, 1998. ISBN 3-468-41070-9.

BEDÜRFTIG, F. Třetí řišse a druhá světová válka. Lexikon nèmeckého nacionálního socialismu 1933-1945. Praha: Prostor. 2004. ISBN: 80-7260-109-1.

BERAN, L. J. Odeprèná integrace. Systémová analýza sudetoněmecké politiky v Československé republice 1918-1938. Praha: Pulchra, 2009, ISBN: 978-80-87377-02-4.

BRÜHL R. a kol. Wörterbuch zur Deutschen Militärgeschichte A/Me. Berlin: Militärverlag der Deutschen Demokratischen Republik, 1985. ISBN: 3-327-00239-8.

CIHLÁ̌̌, J. Těžká léta na Orlickoústecku 1929-1939. Ústí nad Orlicí: Oftis. ISBN: 80-86042-34-0.

HERB, H. Neonazismus in der Bundesrepublik Deutschland und staatliche Reaktionen. Wiesbaden: Verlag Das Junge Wort, 1980. ISBN neuvedeno.

KÖSSL, J. ŠTUMBAUER, J. WAIC, M. Vybrané kapitoly z dějin tělesné kultury. Praha: Karolinum 2004, ISBN: 978-80-246-1566-0.

KOLÁ̌̌, F. Bojkoty olympijských her. In SLEPIČKOVÁ, I. - SLEPIČKOVÁ, P. (eds.): Sport a politika. Praha: Univerzita Karlova, Fakulta tělesné výchovy a sportu, 2010, s. 107-115. ISBN 978-80-86317-82-3. MAREŠ, M. Pravicový extremismus a radikalismus v České republice. Brno: Barrister \& Principal, Centrum strategických studií, 2003. ISBN: 80-86598-45-4. 
MAREŠ, M. Terorismus $v$ ČR. Brno: Centrum strategických studií, 2005. ISBN: 80-903333-8-9.

MAREŠ, M. Symboly uživané extremisty na území ČR v současnosti. Praha: Ministerstvo vnitra ČR., 2006. ISBN neuvedeno.

MAREŠ, M. - SMOLÍK, J. - SUCHÁNEK, M. Fotbaloví chuligáni. Evropská dimenze subkultury. Brno: Centrum strategických studií - Barrister \& Principal. ISBN: 80-903333-0-3.

MILIOPOULOS, L. Strategische Ansätze, Potentiale und Perspektiven der NPD. In BACKES, U. STEGLICH, H. (Hrsg.): Die NPD. Erfolgsbedingungen einer rechtsextremistischen Partei. Baden Baden: Nomos, 2007, s. 121-141. ISBN: 978-3-8329-3122-3.

PAVELKA, R. - STICH, J. : Úpoly. Praha: Oddělení úplových sportů, Katedra technických a úpolových sportů [online], FTVS UK, 2011, [cit. 2011-05-01]. Dostupné na WWW < http://www.ftvs.cuni.cz/katedry/ktus/upolove.php > ISBN neuvedeno.

SMOLÍK, J. Fotbalové chuligánství. Historie, teorie a politizace fenoménu. Karlovy Vary: VNP, 2008. ISBN: 978-80-903556-3-7.

RALPHOVÁ-LEWISOVÁ, B. Hitlerova mládež. Hitlerjugend ve válce a míru 1933-1945. Praha: Svojtka \& Co. 2001. ISBN: 80-7237-386-2. 